\title{
Broadband Properties of Dielectric Antennas Compared with Metallic Antennas
}

\author{
Andersen, J. Bach
}

Published in:

1st European Microwave Conference

Link to article, DOI:

10.1109/EUMA.1969.331925

Publication date:

1969

Document Version

Publisher's PDF, also known as Version of record

Link back to DTU Orbit

Citation (APA):

Andersen, J. B. (1969). Broadband Properties of Dielectric Antennas Compared with Metallic Antennas. In 1st European Microwave Conference (pp. 397-397). IEEE. https://doi.org/10.1109/EUMA.1969.331925

\section{General rights}

Copyright and moral rights for the publications made accessible in the public portal are retained by the authors and/or other copyright owners and it is a condition of accessing publications that users recognise and abide by the legal requirements associated with these rights.

- Users may download and print one copy of any publication from the public portal for the purpose of private study or research.

- You may not further distribute the material or use it for any profit-making activity or commercial gain

- You may freely distribute the URL identifying the publication in the public portal

If you believe that this document breaches copyright please contact us providing details, and we will remove access to the work immediately and investigate your claim. 
BROADBAND PROPERTIES OF DIELECTRIC ANTENINAS COMPARED WITH

METALLIC ANTENNAS

J. Bach Andersen

The usual thin, metallic dipole antenna is characterized by rapid variations in impedance as a function of frequency. This puts a basic limitation on the frequency range over which the antenna can be adequately matched to a transmission.line, or put differently, the gain-bandwidth product is small and tends to zero, when the thickness of the rod tends to zero. Physically this is due to the transmission line like character of metallic antennas with only little radiation from the travelling waves along the rod and large reflection from the end.

It will be shown that this situation can be significantly improved by replacing the metal with a dielectric of proper permittivity. Especially in the microwave region this looks like a very pronising technique since suitable low loss materials exist.

The dispersion characteristics of the waves on the infinite cylinder are most easily understood as a coupling between two simpler systems, an external wave on a perfectly conducting cylinder $(|\varepsilon|=\infty)$ and an internal wave in a waveguide with a magnetic wall. When the phase velocities of the uncoupled waves are equal, a coupling takes place, which results in a surface wave and a leaky wave. As the frequency increases the modal spectrum oscillates between a not too slow surface wave and a fast leaky wave, when the excitation is external to the surface. At the cut-offs of the surface waves the external fields are identical to those of a metal cylinder, below cut-off the leaky wave is present, above cut-off the surface wave. The influence of the different wave types on the admittance of the infinite cylinder is discussed.

It turns out that the conductance of the infinite cylinder is almost equal to that of the metal over an appreciable frequency band in the leaky wave region, while the decay rate along the cylinder is much larger. Thus the effect of the end reflection is reduced and the gain-bandwidth product increased.

Experiments in $L$ and $S$ band on dielectric rods with a permittivity of 15 verify the general ideas and the detailed calculations. In the surface wave region the influence of the end is increased and the bandwidth is decreased. This deficiency is overcome by using a conical instead of a cylindrical shape, whereby most of the energy will radiate before returning to the feed. An experimental result shows an input admittance, which is constant within 10\% over a $3: 1$ frequency range, a metallic antenna of the same dimensions has a 300\% variation over the same frequency range.

J. Bach Andersen is with the Laboratory of Electromagnetic Theory, Technical University of Denmark, Lyngby, Denmark. The work was performed while the author was visiting Polytechnic Institute of Brooklyn, N.Y., U.S.A. 